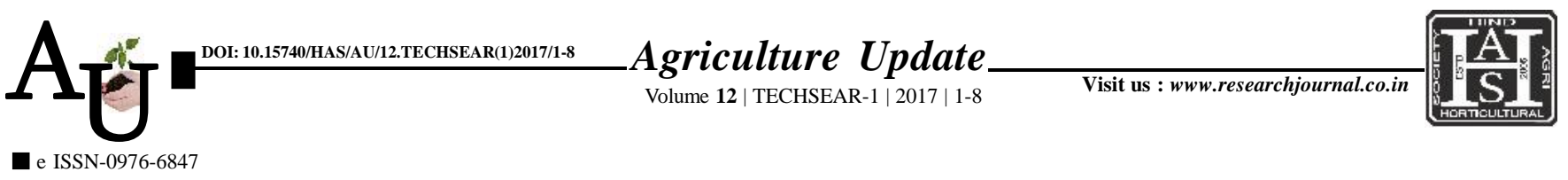

\title{
Research Article: Probiotics: Anew approach for post harvest disease management and quality retension in grapes
}

P. SRILATHA AND S.G. BORKAR

Article Chronicle:

Received :

08.02.2017;

Revised :

20.02.2017;

Accepted :

01.03.2017

KEY WoRds :

Probiotics, Post

harvest pathogens,

Disease management

Author for correspondence :

\section{P. SRILATHA}

Department of Plant

Pathology and

Agriculture

Microbiology, Mahatma Phule Krishi Vidyapeeth, Rahuri, AHMEDNAGAR (M.S.) INDIA

Email : srilaxmi.11.21@ gmail.com

See end of the article for authors' affiliations HAS/AU/12.TECHSEAR(1)2017/1-8.

\section{BACKGROUND AND OBJECTIVES}

A fruit forms an important component of human diet as these are rich sources of minerals, vitamins, aminoacids, anthocyanidins and immune system boosters. Among various fruits, grape berries are a high priced fruits in India. In India, grape is cultivated over an area of 1.1 lakh ha with a productivity of $11.1 \mathrm{MT} /$ ha (Anonymous, 2011) and total production

SUMMARY : Use of probiotics for the control of post-harvest diseases has opened new avenue in the management of post-harvest plant pathogens and organic farming. Such probiotics has never been used in the crop protection programme in agriculture. The post-harvest pathogens particularly Rhizopus, Aspergillus, Penicillium and Alternaria can be checked as a post-harvest pathogen by sprays of probiotics under natural field conditions when the loads of inoculums of these post-harvest pathogens are less in fruits. Application of probiotic as pre-harvest field spray helps to manage the post-harvest disease. The pre-harvest field application of commercial probiotics Sporocheck and MPKV probiotics has beneficial effect for management of post-harvest pathogens Aspergillus. Commercial Probiotics Darolac and Sacro was not effective in the control of Aspergillus infection. For the control of Rhizopus pathogen MPKV probiotics was effective as compared to commercial probiotics. similarly commercial probiotics Darolac, Sporocheck and MPKV probiotics was effective to inhibit the growth of postharvest pathogens Penicillium and Alternaria on the harvested fruits (having natural load of pathogen inoculums) the efficacy of probiotics against post-harvest pathogens, indicated that probiotics can be used in the management of post harvest disease and there can form an integral part of organic farming system and keeps the grape berries fresh. As the probiotics are consumed orally and beneficial to the human health their presence on the consumable fruits will not have any harmful affect on the human. As the probiotics are known to control pathogenic infections in human and are safe microbial formulations, there use to control post harvest pathogen was studied.

How to cite this article : Srilatha, P. and Borkar, S.G. (2017). Probiotics: A new approach for post harvest disease management and quality retension in grapes. Agric. Update, 12(TECHSEAR-1) : 1-8; DOI: 10.15740/

of 12.35 million MT. Maharashtra state occupies 90,000 ha area with production of one million MT and ranks first in production and productivity with 62.7 per cent of countries total production.

Besides occurrence of regular diseases in grape orchards, post-harvest pathogens also infect the grape bunches in the gardens during humid climatic conditions, and in transit and 